\title{
Intra-Family Torts: From Immunity to Special Rules in Criminal and Civil Law
}

\author{
Salvatore Lucio Patti \\ Professor of Private Law, University of Rome, 'La Sapienza' \\ studiopatti@iol.it
}

\begin{abstract}
This article examines the development of the rules concerning criminal and civil law against family violence. It analyses the social changes and legal evolution from a mutual immunity of spouses to a widespread legal protection of victims of domestic violence. It aims to depict the tendencies towards the application of general tort law in civil law cases and towards special rules providing more and specific protection within criminal law. In this context the article also critically considers the latest international, European and Italian legislation.
\end{abstract}

\section{Keywords}

intra-family tort law - immunity doctrine - 'unity of spouses' - marital rape exemption - female and family protection - Istanbul Convention - Directive 2012/29/EU - Italian law no. 119/2013

In the course of time, the rules concerning criminal and civil law against family violence developed from a mutual immunity of the spouses - in fact of the husband - to a widespread legal protection of victims of domestic violence. With regard to these fundamental changes this article, which is divided into three parts, will examine the evolution of the intra-family tort rules in order to depict the latest international, European and Italian legislation in the field of this subject. The focus will be on tort rules and offenses that do not constitute specific violations of family duties (e.g. maintenance) but which could be 
committed towards anybody (such as violence) and do not find a typical regulation within the family law.

In particular, the first part of the article will examine the former doctrine of interspousal immunity, whose essential element was the 'unity of spouses'. The second part will discuss the decline of the same doctrine and - also as a result of family law reforms in the last century - the following application of general tort rules. Finally, the last part of this article will illustrate the most important recent legislation in criminal law regarding female and family protection, which has been enacted on an international, European and national level. The legislation includes the Council of Europe Convention on preventing and combating violence against women and domestic violence, the Directive 2012/29/EU of the European Parliament and of the Council of 25 October 2012 establishing minimum standards on the rights, support and protection of victims of crime, and replacing Council Framework Decision 2001/220/JHA, as well as the Italian law no. 119/2013, implementing the aforementioned European directive.

\section{The Doctrine of Interspousal Immunity}

\section{1 'Unity of Spouses' and their Mutual Immunity}

The problem of tort liability between husband and wife has been subject to studies in Anglo-American law more than in other legal systems and culminated in a doctrine of interspousal immunity. In order to understand such a doctrine, one needs to know its historical context and grounds, such as the economic dependence of the wife on her husband, the limitation of the wife's legal capacity, including her right to sue and to be sued, etc. In fact, it has to be taken into consideration that in the past marriage meant that even though the married woman formally still had the capacity to own property, the right to use and to enjoy her assets was assigned to her husband, with the consequence that the wife became its mere title holder. ${ }^{1}$ Besides, the act of marriage deprived the woman of her legal capacity to act as well as to be a party to a judicial process, and any actions for the compensation of the damage caused to the married woman could only be initiated by her husband. ${ }^{2}$ This resulted, amongst others, in the unavailability of an independent cause of action between the

1 See McCurdy, 'Torts Between Persons in Domestic Relation', Harvard Law Review 43 (1930) 1030 at 1033-1041.

2 Blackstone, Commentaries on the Laws of England in 4 Books (Oxford: Clarendon Press, 1765) 430. 
spouses. ${ }^{3}$ It therefore appears that the provision granting immunity from tort liability to the party committing a tort within the spouses' relationship constituted the logical corollary of the limitations imposed upon the wife's legal capacity. 4

The justification for such immunity following the marriage was originally deducted from the principle of 'unity of spouses', which stated that husband and wife legally were considered a unity. The 'unity of spouses' doctrine, which has had a huge impact on the former Anglo-American legal thinking throughout the years, led to the principle of 'interspousal immunity' as the basis for the handling of controversies involving injuries between husband and wife as well as to the non-applicability of tort liability rules. Given the fact that the law considered the spouses to be 'one person', the spouses - as one subjective identity - could not be liable when causing damages to one another, whether undertaken wilfully or negligently. This meant that the woman, who was not able to sue except in the name of her husband, for many years, did not have any protection against the latter.

Over the years, when the fiction of the 'unity of spouses' was abolished granting the married women inter alia more property rights, the courts established another basis for the immunity between the spouses, which was then followed for several decades. In particular, the judges supported the protection of family harmony and domestic peace and considered that those principles should prevail over the ones that justified the application of the tort liability rules. ${ }^{5}$ The idea was that involving tribunals in matrimonial conflicts would cause damage to the family harmony and to the domestic peace and should, therefore, be avoided at the expense of any sanctions due to tortious conduct.

Compared to the United States of America, the legal situation in Europe differed with regard to this subject. In fact, aside from England which also had a similar 'unity of spouses' and immunity doctrine, continental legal systems such as those of Germany or Italy did not follow such principles. However, there was no different modus operandi of the rules on tort liability in continental legal systems: The rules regarding tortious conduct were not applied as legal

3 Patti, 'Intra-Family Torts', in: Glendon et al. (eds.) International Encyclopedia of Comparative Law, vol. IV, Persons and Family (Dordrecht, Boston, Lancaster, Tübingen: J.C.B.Mohr and Martinus Nijhoff Publishers, 1998), 1 at 7.

4 Ibid.

5 Brown v. Groster, 262 S. W. 2 d 480 (Ky. 1953) and comment Townsley, Texas Law Review 32 (1953/1954) 884. Only in rare cases it was allowed for the married woman to act against her husband. For an analysis see Albersworth, 'Recognition of New Interests in the Law of Torts', California Law Review 10 (1921/1922) 461 at 471. 
actions generally were not initiated, e.g. the damaged family member refrained from suing judicial relief. ${ }^{6}$

\subsection{The Marital Rape Exemption}

In this context special attention needs to be paid to the marital rape exemption, which provided criminal immunity to the husband regarding the rape of his wife. ${ }^{7}$ This exemption granted to the husband has been developed by the common law as a consequence of the principle of the 'unity of spouses' and was adopted by nearly all American jurisdictions. According to the older case law the spouses were to be considered as one entity, leading to the result that - since the husband "may not rape himself" - rape between the spouses during marriage was simply unimaginable. ${ }^{8}$ Consequently, the principle regarding the 'unity of spouses' not only spared the husband from the application of the civil law rules, but also from criminal prosecution. Another argument used to justify the husband's criminal immunity was based on the property rights he had in relation to his wife. While the husband was entitled to take actions in order to protect his property rights in case of a rape of his wife by a third party, the use of violence by himself against his wife was the equivalent of the exercise of those property rights and thus not to be considered illegal. ${ }^{9}$

The decline of the abovementioned concepts after some decades did not lead, however, to a renouncement of the immunity principle. Instead, the American jurisdiction searched for new grounds on which to base this principle and to guarantee immunity from criminal liability in case of a rape of the married woman by her own husband: the 'consent' given by the former. It was argued that by celebrating marriage the wife also agreed to engage in sexual intercourse with her husband as well as to accept all of his demands. Thus, a refusal from her side would legitimate her husband to use violence towards his spouse. $^{10}$

$6 \quad$ Patti, 'Intra-Family Torts' (n 3$)_{3}$.

7 In common law rape was defined as sexual intercourse by a male with a female, who is not his wife, without her consent, but it was also ruled out between spouses.

8 See decisions recalled by Glasgow, 'The Marital Rape Exemption - Legal Sanction of Spouse Abuse', Journal of Family Law 18 (1980), 565.

$9 \quad$ Ibid.

10 Lord Matthew expressed this concept for the first time in 1847. For full references see Schultz, 'The Marital Exemption of Rape - Past, Present and Future', Detroit College Law Review 11 (1978) 261. On the need for actual consent see Harris, 'Towards a Consent Standard in the Law of Rape', University of Chicago Law Review 43 (1975/1976) 613; Scutt, 'Consent in Rape - The Problem of the Marriage Contract', Monash University Law Review 3 (1977) 255 . 
As regards countries of the Romanic tradition, in Italy, more than in others, tortious conduct of the spouses has been without sanctions. Some old cases had constituted the non-liability of the husband as 'head of the family' for actions taken while exercising the jus corrigendi. In fact, he was granted the right to discipline his wife by "violent but moderate means", as stated by the Italian Supreme Court (Corte di Cassazione) at the beginning of the last century. ${ }^{11}$ However, the 'violent but moderate means' implied that the husband, nevertheless, would be held liable whenever his damaging actions exceeded the normal limits of the jus corrigendi. As a result, even though the husband actually had the power to correct his wife physically, the immunity principle has also never been fully accepted in Italy, and generally, only few legal proceedings can be found. ${ }^{12}$

\section{The Decline of the Immunity Doctrine and the Rise of the Application of General Rules}

Reflecting on the fundamental changes in social customs and traditions, e.g. the conception of equality between husband and wife and the respective family law reforms, the doctrine of interspousal immunity declined in the course of the last century. Nevertheless, and as observed above, the abolition of the 'fiction' of the 'unity of spouses' in the Anglo-American law did not at first lead to a different approach in the legal praxis as courts then based the spouses' immunity upon the idea of protecting family harmony and domestic peace. These principles were deemed to be prevailing and precluded the application of general tort liability rules. Only following legislative interventions (especially in the second half of the 2oth century) by means of statutes providing gradually more and more comprehensive rights for one spouse to sue the other one due to the tortious conduct of the latter, the courts gradually dismissed the idea of immunity. ${ }^{13}$ Corresponding court rulings (e.g. new case law) then established the grounds for further legal actions based on general tort rules. In England such legislative intervention took form in the 'Law Reform Husband

\footnotetext{
11 See Cass. 19 June 1936, Annali di diritto e procedura penale (1937) 138.

12 Longo Dorni, 'In tema di 'ius corrigendi' del marito', Giurisprudenza italiana (1959 II) 305; Patti, 'Intra-Family Torts' (n 3 ) 14.

13 Legal provisions and according court decisions first abandoned the immunity doctrine in property damage cases (Patti, 'Intra-Family Torts' (n 3 ) 11; see for the reasoning of its application nonetheless in personal injuries actions Edmond v. Edmond, 139 Va. $65^{2,}, 124$ S.E. 415 (1924)).
} 
and Wife Act' of 1962 which expressly granted spouses the right to seek damages against each other "as if they were not married". 14

In the continental legal systems, without the obstacle of case law affirming inter-spousal immunity, general tort law could be and was indeed applied, as for instance with regards to the Italian provision of Article 2043 of the Italian Civil Code. ${ }^{15}$ However, the problem arose as to what extent this general application was possible. Within this context, it was discussed in Italy whether or not general norms of civil liability were applicable besides the special norms regulated in the family law book, such as the remedy of divorce. Many authors opposed such a wide scope of application, placing emphasis on the 'closed' character of the family law book and arguing that under a wide scope of application no appropriate treatment of the special relationship between spouses could be granted. ${ }^{16}$ Over time this opinion was overruled in the Italian legal doctrine, with the consequence that general norms of civil liability also governed cases of compensation for damages caused and suffered by family members. ${ }^{17}$

With regard to legal immunity in the field of criminal law the overall picture that has to be drawn differs from the evolution that emerged on the horizon of civil law. It is only at the beginning of the early eighties of the last century that the attitude as to the matter of rape exemption and consequently the

14 Thomson, 'The Reform of Family Law in England', in: Chloros (ed) The Reform of Family Law in Europe (Deventer, Boston a.o.: Kluwer, 1978) 43 at 74; Kahn-Freund, 'Wandlungen des englischen Familienrechts seit 1945', RabelsZ 28 (1964) 232 at 26o, who perceives the 1962 Law as a result of the profound changes that occurred in the family (structures) after the Second World War.

15 Article 2043 Italian Civil Code: "Risarcimento per fatto illecito. Qualunque fatto doloso o colposo che cagiona ad altri un danno ingiusto, obbliga colui che ha commesso il fatto a risarcire il danno." "Compensation for unlawful acts. Any intentional or negligent act that causes an unjustified injury to another obliges the person who has committed the act to pay damages."

16 For a recent critical opinion on the possibility to apply the general rule for tort liability and for references to the older interpretation, see Nicolussi, 'Obblighi familiari di protezione e responsabilità', Europa e diritto privato 4 (2008) 929. Interesting problematic aspects can be also found in Paradiso, 'Famiglia e responsabilità civile endofamiliare', in: Famiglia, Persone e Successioni 7 (2011) 14; Di Rosa, 'Violazione dei dovere coniugali e risarcimento del danno', Familia $4 / 5$ (2008) 3 .

17 E. Carbone, 'La giuridificazione delle relazioni domestiche e i suoi riflessi aquiliani', Familia (2006) 102. In jurisprudence, the most argued affirmation regarding the applicability of the rules for civil offenses also in the relationship between family members can be found in Cass., 10 May 2005, n. 9801, in: Famiglia e diritto (2005) 365; Corriere giuridico (2005) 921. 
jurisdiction changed, even if judicial decisions condemning the tortious conduct of a rape between spouses can be dated as far back, for example in Italy, to the year $1976 .{ }^{18}$ From thereon, it was perceived that the physical integrity of an individual involved a matter of public interest and as a consequence any 'consent' by a married woman to injuries concerning her human body was inadmissible and the respective principle was deemed to be obsolete. ${ }^{19}$ Furthermore, the problem of prior and little convincing argumentation according to which a woman would have had sufficient alternative remedies outside criminal law and to which limitations would have been necessary in order to avoid the risk of abusive false charges, was overcome. ${ }^{20}$ Nevertheless, the evolution of criminal law provisions against violence in families seems, maybe more than in the area of civil law, a continuous 'work in progress' until recent times. In fact, it can be observed that the long-fought application of general rules is de facto not sufficient to protect wives in intra-family violence cases. Under this perspective the development of special norms on the international level, as well as their implementation and consideration on the national level over the last decade, is of particular interest.

\section{$4 \quad$ Special Rules of Criminal Law on Female and Family Protection}

\subsection{Council of Europe Convention on Preventing and Combating Violence against Women and Domestic Violence}

On the international level, the Council of Europe Convention on preventing and combating violence against women and domestic violence (Istanbul Convention), which was opened for signature on May 11, 2011 in Istanbul (Turkey) and which came into force on August 1, 2014 is one of the most interesting legal instruments in the present context. As of June 2015 the Istanbul Convention has been signed by 39 countries, including Italy, ${ }^{21}$ and is the first legally binding instrument creating a broad and comprehensive legal

18 The judgment of an appellate court which had found a husband guilty of rape was affirmed by the Penal Division of Cass. 4 Dec. 1976 no. 2855, in: Rivista Penale (1977 I) 281. The Penal Division not only held the judgment to be consistent with the present law but also referred to constitutional principals regarding human dignity and personal liberty.

19 Harris, 'Towards a Consent Standard in the Law of Rape', University of Chicago Law Review 43 (1975) 613 at 635 .

20 Patti, 'Intra-Family Torts' (n 3 ) $10 \mathrm{s.}$

21 Italian law no. 77/2013, "Ratifica ed esecuzione della Convenzione del consiglio d'Europa sulla prevenzione e la lotta contro la violenza nei confronti delle donne e la violenza domestica fatta a Istanbul l'11 maggio 2011". 
framework. In fact, it focuses on preventing domestic violence and all forms of violence against women, protecting victims as well as prosecuting any offenders. ${ }^{22}$ Moreover, the Convention shall contribute to the elimination of all forms of discrimination against women and promote substantive equality between women and men.

In order to do so, one of the Istanbul Convention's purposes is to promote international co-operation between the undersigned countries, as globalisation often implicates the involvement of persons belonging to different nationalities in cases regarding violence. This aspect refers to a mutual interpretation and application of the Istanbul Convention as well as a close co-operation between authorities, police and courts of different countries in order to guarantee as much protection of the victims as possible.

Several definitions established in the Istanbul Convention are worth mentioning as they reveal a new attitude of the legislator concerning the rights of women. For instance, by examining Article 3 a), according to which 'violence against women' is defined as a violation of human rights and a form of discrimination against women, the relationship between the protection of women, human rights and rules regarding discrimination is illustrated. Moreover, the definition is quite broad and comprises all forms of genderbased violence that result in, or are likely to result in, physical, sexual, psychological or economic harm or suffering to women including rape, stalking or sexual harassment as well as any threat of such acts. Another noteworthy definition is seen in Article $3 b$ ) of the Istanbul Convention concerning 'domestic violence', which means any of the above-mentioned acts that occur within the family or domestic unit, irrespective of biological or legal family ties, whether or not the perpetrator shares or has shared the same residence with the victim. Due to the fact that no joint residence is required, violence committed after the end of a relationship is thus also covered by the definition. Domestic violence mainly comprises the violence between current or former spouses or partners (intimate-partner violence) or the inter-generational violence between parents and children. As one can see, the definition does not refer to just any of the sexes but includes victims and offenders of both sexes. The final definitions worth highlighting are those regarding 'gender' and 'gender-based violence against women' set forth in Articles $3 \mathrm{c}$ ) and d) of the Istanbul Convention. The former means the socially constructed roles, behaviours, activities and attributes that a given society considers appropriate for women

22 Article 1 a) Council of Europe Convention on preventing and combating violence against women and domestic violence. 
and men. In order to overcome these gender roles, Article 12 (1) of the Istanbul Convention actually foresees that the obligation to eradicate prejudices, customs, traditions and any other practices that are based on the idea of the inferiority of women or on stereotyped roles for women and men is one of the general obligations of the Istanbul Convention. The second kind of conduct (gender-based violence against women) is defined as violence directed against a woman because of the fact that she is a woman or because the violence affects women disproportionately to men.

The countries having signed the Istanbul Convention are obliged to criminalise various offences, inter alia psychological violence, stalking, physical violence, sexual violence including rape, forced marriage, female genital mutilation, forced abortion and forced sterilisation as well as sexual harassment (see Articles 33 to 40 of the Istanbul Convention). The protection becomes effective in the light of Article $5^{2}$ of the Istanbul Convention, according to which the judge is entitled to order the party committing domestic violence to leave the victim's household and to prohibit any further contact.

\subsection{Directive 2012/29/EU of the European Parliament and of the Council}

The Directive 2012/29/EU of the European Parliament and of the Council of October $25,2012^{23}$ (Directive) is another noteworthy international treaty concerning the matter in question that requires being examined in detail. As mentioned in Recital 13 of the Directive, the latter applies in relation to "criminal offences committed in the Union and to criminal proceedings that take place in the Union". ${ }^{24}$

According to the Directive's subtitle, it establishes minimum standards on the rights, support and protection of victims of crimes. In particular, Article 1 (1) of the Directive entitled "Objectives" states that the purpose of this Directive is to ensure that victims of crime receive appropriate information, support and protection and are able to participate in criminal proceedings. Article 2 (1) a) of the Directive provides the definition of 'victim' as a "natural person who has suffered harm, including physical, mental or emotional harm or economic loss which was directly caused by a criminal offence" or "family members or a person whose death was directly caused by a criminal offence and who have suffered harm as a result of that person's death". With this regard, 'family members' means "the spouse, the person who is living with the victim in a committed

\footnotetext{
23 Directive 2012/29/EU of the European Parliament and of the Council of 25th October 2012 establishing minimum standards on the rights, support and protection of victims of crime, and replacing Council framework Decision 2001/220/JHA.
}

24 See Recital 13 of the Directive. 
intimate relationship, in a joint household and on a stable and continuous basis, the relatives in direct line, the siblings and the dependents of the victim", see Article 2 (1) b) of the Directive. Comparing the aforesaid objectives set forth in the Directive with the purposes of the Istanbul Convention provided for under its Article 1, the Istanbul Convention can be considered a very special treaty of rules as it aims to prevent and combat violence against women in particular and domestic violence. The Directive, on the other hand, is a more general treaty and provides protection for any "victims of crimes", regardless of the victim's sex.

However, violence in relationships and families as well as violence against women in particular are mentioned in the Recitals of the Directive. For instance, Recital 18 of the Directive refers to violence committed in a close relationship and establishes that such an offence is committed by a person who is a current or former spouse or partner or family member of the victim, whether or not the offender shares or has shared the same household with the victim. In accordance with what has been foreseen in the Istanbul Convention, the Directive does not necessarily require that the person committing the violence and the person being victim to such violence do live or have lived together in order for the Directive to be applied. As in these cases the offending person is a person whom the victim of violence should be able to trust, the Directive acknowledges that victims of violence committed while being in a close relationship might need special protection measures. The Directive even goes one step further and recognises that this type of violence mainly affects women and that the situation can be even worse if the woman is dependent on the offender economically, socially or as regards her right to residence. ${ }^{25}$

The Directive, just like the Istanbul Convention, pays special attention to the protection against gender-based violence. ${ }^{26}$ For example, Recital 17 of the Directive deals with such kind of violence defining it as violence that is directed against a person because of that person's gender, gender identity or gender expression or that affects persons of a particular gender disproportionally. This is, of course, inclusive of but not limited to women, and also takes into account physical, sexual and psychological as well as economic violence.

Furthermore, under Chapter 2 the Directive contains several provisions for information and support for the victims, including, inter alia, the victim's right to receive information from a first contact with a competent authority (Article 4), the victim's right to receive information about his/her case (Article 5), or the victim's right to access victim support services (Article 8).

25 Recital 18 of the Directive.

26 See Recitals 9, 17, 38, 56, 57, 61 of the Directive. 
Due to the fact that there are a lot of violence-related cases between persons of different nationalities, Article 7 of the Directive foresees the victim's right to interpretation and translation of the information essential to exercise his/her rights in criminal proceedings. ${ }^{27}$ Chapter 3 of the Directive, on the other hand, is dedicated to the victim's rights when participating in criminal proceedings, while Chapter 4 of the Directive governs the victim's rights concerning his/her protection.

According to Article 27 of the Directive, the Member States shall bring into force the laws, regulations and administrative provisions necessary to comply with this Directive by November 16, 2015.

While the Directive surely strengthens the rights of the victims, it consequently weakens the legal status of the person accused of having committed violence. By way of example, Article 6 of the Directive foresees that victims shall be notified when the person who is remanded in custody, prosecuted or sentenced for criminal offences concerning them is released from or has escaped detention. The understandable and legitimate need to protect victims from further violent attacks, however, must not hide the fact that the offender remanded in custody has to be presumed innocent. Indeed, it is not yet determined at that time whether he has committed the crime and whether he is a (further) threat to the victim. The same applies to Article 22 of the Directive, which provides for a timely and individual assessment, in accordance with national procedures, to identify specific protection needs of the victims and to determine whether and to what extent they would benefit from special measures in the course of criminal proceedings. Such timely performance of the assessment of the victim could be in conflict with the presumption of innocence of the person accused. Given the fact that the lack of an actual victimisation cannot be ruled out during the preliminary proceedings, at that point of time one could only speak of a presumed victim. Therefore, an early determination of the accusing person as a victim with specific protection needs could be close to a prejudgment of the offender contrary to the rule of law.

When examining the situation in Italy, its newspapers regularly report on cases of marital and domestic violence leading to the death of the wife. This might also be a consequence of stress resulting from the current difficult economic situation in Italy. Nevertheless, it underlines the necessity of protection of the victims as well as prevention of such crimes. In the past and present in

27 Article 7 (1) of the Directive: 'Member States shall ensure that victims who do not understand or speak the language of the criminal proceedings concerned are provided, upon request with interpretation in accordance with their role in the relevant criminal justice system in criminal proceedings, free of charge (...).' 
Italy, the situation regarding marital and domestic violence did not and does not differ from that in other European countries. However, it needs to be stressed that Italian judges, already from the last century onwards, granted compensation for victims of intra-family torts. Such compensation included not only the economic loss suffered but, more importantly, non-material losses like moral damage, mental suffering etc.

In the light of the pressure to adjust the Italian law to the international conventions, the European directives and the jurisdiction of the European Court of Human Rights ${ }^{28}$ as well as the continuous news regarding domestic violence, the Italian legislator, by means of the Italian law no. $119 / 2013,{ }^{29}$ implemented the aforementioned Directive and also took into consideration what has been established in the provisions of the Istanbul Convention. A significant novelty has been the new provision regarding the immediate removal of the perpetrator from the family home and the order for them to stay away from the victim, namely Article 384 of the Italian Code of Criminal Procedure. In case of such a removal and restraining order, the victim has the right to receive information from the first contact with a competent authority. This is, in fact, of great importance, as very often the victims - mostly women - do not dispose of any knowledge concerning these new rules.

\section{Conclusion}

"Principles belonging to other historical periods may not be the instrument of injustice in a profoundly different community."30 This qotation describes the core incentive behind, and at the same time the nature of, the changes identified when observing the development of the rules concerning criminal and civil law against family violence over the last century until today. Both

28 See the rulings of the European Court of Human Rights, which on several occasions has interpreted Article 8 of the European Convention on Human Rights as not only imposing negative obligations on States - such as the prohibition of arbitrary interference violating the privacy - but also positive ones, in particular with regard to the physical and psychic integrity and the self-determination of the person in the domestic contest: M.C. v. Bulgaria, no. 39272/98, ECHR 2003-XII, para. 187; Bevacqua v. Bulgaria, no. 71127/01, ECHR 2008-VI, para. 84; E.S. and Others v. Slovakia, no. 8227/04., ECHR 2009-IX, para. 40.

29 Italian law no. $119 / 2013$, 'Disposizioni urgenti in materia di sicurezza e per il contrasto della violenza di genere, nonché in tema di protezione civile e di commissariamento delle province'.

30 Patti, 'Intra-Family Torts' (n 3) 12, referring to the judgment Surratt v. Thompson, 212 Va. 193, 183 S.E.2d 202 (1971). 
Anglo-American and continental Europe legislations changed their perspective in this legal field, which was accompanied and influenced by profound social evolutions, mainly in the area of gender equality.

The methods and ways in which those changes were implemented, e.g. case law, new legislative acts etc., of course differed from country to country due to the varying legal systems. Nonetheless, the common aim that has been reached by taking these different paths regarding family torts is an application of general tort law in civil law cases and, as it can be noted in more recent developments, a tendency towards special rules providing more and specific protection within criminal law. It is with regard to the latter that the latest international, European and Italian legislative developments represent the modern understanding of necessary requirements for granting an adequate protection of family violence victims. Even though the level of protection in this field has never been on a higher legislative level, reality and practice will evaluate and show the actual impact of these new rules. Looking at an alarmingly high number of domestic violence cases even in recent times, it seems that the legislation still needs to prove its capacity of being a valuable instrument for achieving and securing the ideas and standards of modern society. ${ }^{31}$

31 For a critique, see also Marandola, 'Nuove norme in materia di violenza di genere: Aspetti processuali', in: Studium iuris 20 (7) (2014) 527. 